\title{
Proposal of Six New Species in the Genus Aureobacterium and Transfer of Flavobacterium esteraromaticum Omelianski to the Genus Aureobacterium as Aureobacterium esteraromaticum comb. nov.
}

\author{
AKIRA YOKOTA, ${ }^{1 *}$ MARIKO TAKEUCHI, ${ }^{1}$ TAKESHI SAKANE, ${ }^{1}$ AND NOBERT WEISS ${ }^{2}$ \\ Institute for Fermentation, Osaka, 17-85, Juso-honmachi 2-chome, Yodogawa-ku, Osaka 532, Japan, ${ }^{1}$ and \\ Deutsche Sammlung von Mikroorganismen und Zellkulturen GmbH, D-3300 Braunschweig, Germany ${ }^{2}$
}

\begin{abstract}
Twelve strains placed in the genera Flavobacterium, Pseudomonas, and Aureobacterium, including soil isolates, were characterized taxonomically. On the basis of morphological, physiological, and chemotaxonomic data, as well as DNA-DNA hybridization data, we propose that 11 of these strains should be classified in the genus Aureobacterium as new combinations or new species, as follows: Aureobacterium esteraromaticum comb. nov. (type strain, IFO 3751 [= ATCC 8091]), Aureobacterium arabinogalactanolyticum sp. nov. (type strain, IFO 14344), Aureobacterium keratanolyticum sp. nov. (type strain, IFO 13309), Aureobacterium luteolum sp. nov. (type strain, IFO 15074 [= DSM 20143]), Aureobacterium schleiferi sp. nov. (type strain, IFO 15075 [= DSM 20489]), Aureobacterium terrae sp. nov. (type strain, IFO 15300), and Aureobacterium trichothecenolyticum sp. nov. (type strain, IFO 15077 [ = JCM 1358]). Whereas the peptidoglycan type of members of this genus is considered to be B2 $\beta$, the new species $A$. keratanolyticum was shown to have a new peptidoglycan type, murein variation B2 $\alpha$. An emended description of the genus Aureobacterium is presented.
\end{abstract}

The genus Aureobacterium was proposed by Collins et al. (2), and the following six species have been described previously (8): Aureobacterium liquefaciens, Aureobacterium flavescens, Aureobacterium terregens, Aureobacterium saperdae, Aureobacterium barkeri, and Aureobacterium testaceum.

During the course of a taxonomic study of the Flavobacterium strains in the Institute for Fermentation at Osaka (IFO) culture collection, we found that the aromatic compound producers Flavobacterium esteraromaticum $(18,23)$ and "Flavobacterium suaveolens" (24) and the keratan sulfate endo- $\beta$-galactosidase (keratanase) producer Pseudomonas sp. strain IFO $14344^{\mathrm{T}}(\mathrm{T}=$ type strain) $(16,17)$ were members of the genus Aureobacterium (26). To determine the taxonomic position of these organisms, we examined their physiological and chemotaxonomic characteristics, as well as the characteristics of some soil isolates and strains designated Aureobacterium sp., and compared our results with data for previously described species of the genus Aureobacterium.

In this paper we describe the characteristics of 12 strains of Aureobacterium species. We propose six new species and one new combination in the genus Aureobacterium for these strains on the basis of morphological, physiological, biochemical, and DNA-DNA hybridization data.

\section{MATERIALS AND METHODS}

Bacterial strains and culture conditions. The bacterial strains which we studied are listed in Table 1. Biomass for the chemical analyses was prepared by growing the strains at $28^{\circ} \mathrm{C}$ with aerobic shaking in PY medium supplemented with Bacto brain heart infusion (Difco Laboratories, Detroit, Mich.) (PY-BHI medium), which contains $1 \%$ peptone, $0.2 \%$ yeast extract, $0.2 \%$ brain heart infusion, $0.2 \% \mathrm{NaCl}$, and

\footnotetext{
${ }^{*}$ Corresponding author.
}

$0.2 \%$ D-glucose ( $\mathrm{pH} 7.0$ ). Cells were harvested by centrifugation, washed with water, and lyophilized.

Morphological, physiological, and biochemical characteristics. Unless otherwise indicated, all of the tests were carried out at $28^{\circ} \mathrm{C}$. Cell morphology was determined by examining cells grown on PY-BHI agar. Motility was determined by the hanging drop method. Catalase activity was determined by bubbling in a $3 \%$ hydrogen peroxide solution. Oxidase activity was determined by the oxidation of $1 \%$ tetramethyl$p$-phenylenediamine on filter paper. Acid production from carbohydrates was studied in a medium containing $0.3 \%$ peptone, $0.25 \% \mathrm{NaCl}, 0.003 \%$ bromcresol purple, and $0.5 \%$ carbohydrate ( $\mathrm{pH} \mathrm{7.2)} \mathrm{(31).} \mathrm{Assimilation} \mathrm{of} \mathrm{organic} \mathrm{acids}$ was studied in a medium containing $0.5 \%$ organic acid (sodium salt), $0.02 \%$ D-glucose, $0.01 \%$ yeast extract, $0.01 \%$ Trypticase (BBL), $0.1 \% \mathrm{~K}_{2} \mathrm{HPO}_{4}, 0.5 \% \mathrm{NaCl}, 2 \%$ agar, and $12 \mathrm{mg}$ of phenol red per liter ( $\mathrm{pH} 7.0)(31)$. Nitrate reduction and hydrolysis of starch, gelatin, casein, and esculin were tested by the methods described by Cowan and Steel (3).

Peptidoglycan analysis. Cell walls were prepared from ca. $500 \mathrm{mg}$ (dry weight) of cells by mechanical disruption with an ultrasonic oscillator and were purified as described by Schleifer and Kandler (22). The amino acid compositions of complete wall hydrolysates were determined with a model LC-6AD high-performance liquid chromatography (HPLC) apparatus (Shimadzu Co., Ltd., Kyoto, Japan) equipped with a Wakopak WS-PTC column (Wako Pure Chemical Industries, Ltd., Osaka, Japan) phenylthiocarbamoyl derivatives according to the manufacturer's instructions (29). The amino acid compositions and isomers of diaminopimelic acid were determined by developing preparations on cellulose thin-layer chromatography plates (Tokyo Kasei Co., Ltd., Tokyo, Japan), using two-dimensional descending chromatography as described by Harper and Davis (5). The configurations of the amino acids were determined by measuring the amino acid contents of the hydrolysates before and after incubation with $\mathrm{D}$ - and L-amino acid oxidase (alanine and homoserine), L-lysine decarboxylase (lysine), L-ornithine 
TABLE 1. Bacterial strains used

\begin{tabular}{|c|c|c|c|c|}
\hline Species & $\begin{array}{c}\text { Strain } \\
\text { (IFO no.) }\end{array}$ & Other designation $^{a}$ & $\begin{array}{l}\text { Reference(s) } \\
\text { or source }\end{array}$ & Proposed reclassification \\
\hline $\begin{array}{l}\text { A. liquefaciens } \\
\text { A. flavescens } \\
\text { A. terregens } \\
\text { A. saperdae } \\
\text { A. barkeri } \\
\text { A. testaceum } \\
\text { F. esteraromaticum } \\
\text { "F. suaveolens" } \\
\text { Aureobacterium sp. } \\
\text { Pseudomonas sp. } \\
\text { Aureobacterium sp. } \\
\text { Aureobacterium } \mathrm{sp} \text {. } \\
\text { Aureobacterium } \mathrm{sp} \text {. } \\
\text { Aureobacterium } \mathrm{sp} . \\
\text { Aureobacterium } \mathrm{sp} \text {. } \\
\text { Aureobacterium } \mathrm{sp} . \\
\text { Aureobacterium } \mathrm{sp} \text {. } \\
\text { Aureobacterium } \mathrm{sp} .\end{array}$ & $\begin{array}{l}15037^{\mathrm{T}} \\
15039^{\mathrm{T}} \\
12961^{\mathrm{T}} \\
15038^{\mathrm{T}} \\
15036^{\mathrm{T}} \\
12675^{\mathrm{T}} \\
3751^{\mathrm{T}} \\
3752 \\
14344^{\mathrm{T}} \\
13309^{\mathrm{T}} \\
15300^{\mathrm{T}} \\
15301 \\
15302 \\
15303 \\
15077^{\mathrm{T}} \\
15074^{\mathrm{T}} \\
15075^{\mathrm{T}} \\
15076\end{array}$ & $\begin{array}{l}\text { ATCC } 3647^{\mathrm{T}} \\
\text { ATCC } 13348^{\mathrm{T}} \\
\text { ATCC } 13345^{\mathrm{T}} \\
\text { ATCC } 19272^{\mathrm{T}} \\
\text { ATCC } 15954^{\mathrm{T}} \\
\text { ATCC } 15829^{\mathrm{T}} \\
\text { ATCC } 8091^{\mathrm{T}} \\
\text { ATCC } 958\end{array}$ & $\begin{array}{l}18 \\
24 \\
9 \\
16,17 \\
\text { Soil } \\
\text { Soil } \\
\text { Soil } \\
\text { Soil } \\
15 \\
27 \\
21 \\
21\end{array}$ & $\begin{array}{l}\text { A. esteraromaticum } \\
\text { A. esteraromaticum } \\
\text { A. arabinogalactanolyticum } \\
\text { A. keratanolyticum } \\
\text { A. terrae } \\
\text { A. terrae } \\
\text { A. testaceum } \\
\text { A. testaceum } \\
\text { A. trichothecenolyticum } \\
\text { A. luteolum } \\
\text { A. schleiferi } \\
\text { A. schleiferi }\end{array}$ \\
\hline
\end{tabular}

a ATCC, American Type Culture Collection, Rockville, Md.; DSM, Deutsche Sammlung von Mikroorganismen und Zellkulturen GmbH, Braunschweig, Germany; JCM, Japan Collection of Microorganisms, The Institute of Physical and Chemical Research (RIKEN), Wako, Japan.

decarboxylase (ornithine), and L-glutamic acid decarboxylase (glutamic acid) by using the method of Kandler and König (7).

Peptidoglycan structure was determined by the method of Schleifer and Kandler (22). Partial acid hydrolysates were subjected to by two-dimensional thin-layer chromatography, and peptides were identified on the basis of their chromatographic mobilities and staining characteristics (22). The $\mathrm{N}$-terminal amino acid of the interpeptide bridge was determined by dinitrophenylation of the undegraded peptidoglycan (22).

Cell wall sugar analysis. Cell walls were hydrolyzed with 2 $\mathrm{N} \mathrm{HCl}$ at $100^{\circ} \mathrm{C}$ for $2 \mathrm{~h}$, dried in vacuo, and then analyzed as described by Mikami and Ishida (11), using a model LC-5A HPLC apparatus (Shimadzu Co., Ltd.) equipped with a Shim-pack ISA $07 / \mathrm{S} 2504$ column $(250$ by $4 \mathrm{~mm})$ and a Shimadzu model RE-530 spectrofluorometer.

Glycolyl analysis. Glycolate tests were performed as described by Uchida and Aida (28).

Analysis of cellular fatty acids. Fatty acids were extracted from $50 \mathrm{mg}$ (dry weight) cells by acid methanolysis and were examined by using a model GC-9A gas-liquid chromatography apparatus (Shimadzu Co., Ltd.) equipped with a glass column ( $2 \mathrm{~mm}$ by $5 \mathrm{~m}$ ) containing $10 \%$ diethyleneglycol succinate on Chromosorb $\mathrm{W}$ at $180^{\circ} \mathrm{C}(25)$.

Analysis of polar lipids. Free lipids were extracted from $100 \mathrm{mg}$ (dry weight) of cells, purified by the method of Minnikin et al. (13), and examined by two-dimensional thin-layer chromatography, using Kieselgel $60 \mathrm{~F}_{254}$ plates. Lipids were visualized by spraying the plates with $10 \%$ molybdophosphoric acid in ethanol and then heating them at $140^{\circ} \mathrm{C}$ for $10 \mathrm{~min}$. The following specific spray reagents were also used; $\alpha$-naphthol for detection of sugars and ninhydrin for detection of amino groups.

Analysis of mycolic acids. Mycolic acids were analyzed by the method of Minnikin et al. (12).

Analysis of isoprenoid quinones. Menaquinones were extracted from $200 \mathrm{mg}$ (dry weight) of cells with chloroformmethanol $(2: 1$, vol/vol), purified by thin-layer chromatography in which benzene was used as the solvent, extracted with diethyl ether, dried by using a nitrogen stream, and then analyzed by HPLC, using a Shimadzu model LC-5A apparatus equipped with a Zorbax octyldecyl silane column (4.6 by $150 \mathrm{~mm}$ ).

DNA base composition. DNA was obtained by the method of Saito and Miura (19). The $\mathrm{G}+\mathrm{C}$ content of the DNA was determined by the method described by Mesbah et al. (10) after treatment with P1 nuclease and alkaline phosphatase and by HPLC by using a Shimadzu model LC-6AD apparatus equipped with a Comosil $5 \mathrm{C}_{18}$-AR column ( 4.6 by 150 mm; Nacalai Tesque, Inc., Tokyo, Japan).

DNA-DNA hybridization. DNA-DNA hybridization was performed fluorometrically in microdilution wells by using biotinylated DNA (4).

\section{RESULTS AND DISCUSSION}

Morphological, physiological, and biochemical characteristics. All of the strains studied were gram-positive rods that were frequently arranged at an angle to give $\mathrm{V}$ forms. All strains grew well on PY-BHI agar at 25 to $30^{\circ} \mathrm{C}$, and the color of the colonies was yellow for all strains except IFO $14344^{\mathrm{T}}$, whose colonies were white. Among the 12 reclassified strains, strains IFO $3751^{\mathrm{T}}$, IFO 3752 , IFO 15302, and IFO 15303 exhibited motility. The tests for which all 12 strains gave positive results were the tests for catalase formation and hydrolysis of esculin, while all 12 strains gave negative results in oxidase and indole formation tests. None of the strains except IFO 15302 and IFO 15303 produced acid from the sugars examined (Table 2). Organic acids were utilized in various combinations (Table 2). None of the strains required terregens factor (2) for growth.

Chemical characteristics. The chemical characteristics of the test strains are summarized in Table 3. The amino acid analysis and determination of the configurations of the amino acids in the cell wall hydrolysates revealed the presence of D-ornithine, D-alanine, D-glutamic acid plus hydroxyglutamic acid, L-homoserine, and glycine (molar ratio, ca. $1: 1: 1: 1: 2$ ) in all strains except strain IFO $13309^{\mathrm{T}}$, whose amino acids were D-ornithine, L-ornithine, D-alanine, D-glutamic acid plus hydroxyglutamic acid, and glycine (molar ratio, ca. 1:1:1:1:1). Homoserine was not present. In addi- 


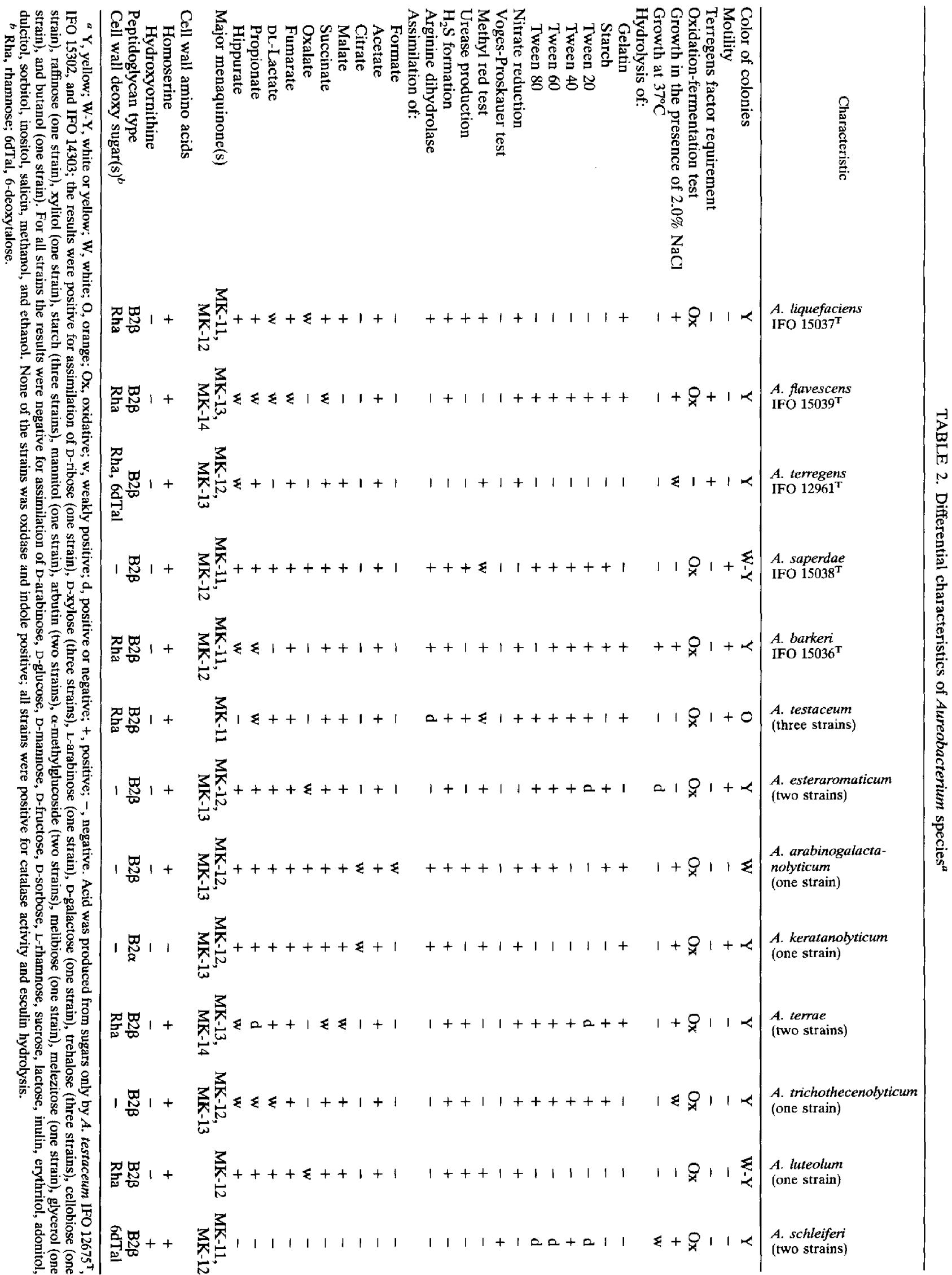


TABLE 3. Chemotaxonomic characteristics of Aureobacterium strains ${ }^{a}$

\begin{tabular}{|c|c|c|c|c|c|c|c|}
\hline Species & $\begin{array}{c}\text { Strain } \\
\text { (IFO no.) }\end{array}$ & $\begin{array}{c}\mathrm{G}+\mathrm{C} \\
\text { content } \\
(\mathrm{mol} \%)\end{array}$ & $\begin{array}{c}\text { Major } \\
\text { menaquinone(s) }\end{array}$ & $\begin{array}{l}\text { Peptido- } \\
\text { glycan } \\
\text { type }\end{array}$ & $\begin{array}{l}\text { Amino acids in } \\
\text { the cell wall }\end{array}$ & Polar lipids ${ }^{c}$ & $\begin{array}{l}\text { Cell wall } \\
\text { sugar(s) }\end{array}$ \\
\hline A. liquefaciens & $15037^{\mathrm{T}}$ & 68.6 & MK-11,MK-12 & $\mathrm{B} 2 \beta$ & L-Hsr,D-Orn & DPG,PG,GL & Rha \\
\hline A. flavescens & $15039^{\mathrm{T}}$ & 66.9 & MK-13,MK-14 & $\mathrm{B} 2 \beta$ & L-Hsr,D-Orn & DPG,PG,GL & Rha,Gal,Glc \\
\hline A. terregens & $12961^{\mathrm{T}}$ & 68.6 & MK-12,MK-13 & $\mathrm{B} 2 \beta$ & L-Hsr,D-Orn & DPG,PG,GL & Rha,6dTal,Gal \\
\hline A. saperdae & $15038^{\mathrm{T}}$ & 69.1 & MK-11,MK-12 & $\mathrm{B} 2 \beta$ & L-Hsr,D-Orn & DPG,PG,GL & Gal,Glc \\
\hline A. barkeri & $15036^{\mathrm{T}}$ & 68.7 & MK-11,MK-12 & $\mathrm{B} 2 \beta$ & L-Hsr,D-Orn & DPG,PG,GL & Rha,Gal,Glc \\
\hline A. testaceum & $12675^{\mathrm{T}}$ & 67.7 & MK-11 & $\mathrm{B} 2 \beta$ & L-Hsr, D-Orn & $\mathrm{DPG}, \mathrm{PG}, \mathrm{GL}$ & Rha,Man,Gal \\
\hline A. testaceum & 15302 & 70.1 & MK-11,MK-10 & $\mathrm{B} 2 \beta$ & L-Hsr,D-Orn & DPG,PG,GL & Rha,Gal \\
\hline A. testaceum & 15303 & 69.7 & MK-11 & $\mathrm{B} 2 \beta$ & L-Hsr,D-Orn & DPG,PG,GL & Rha,Gal \\
\hline A. esteraromaticum & $3751^{\mathrm{T}}$ & 68.8 & MK-12,MK-13 & $\mathrm{B} 2 \beta$ & L-Hsr,D-Orn & DPG,PG,GL & Gal,Glc \\
\hline A. esteraromaticum & 3752 & 67.7 & MK-12,MK-13 & $\mathrm{B} 2 \beta$ & L-Hsr, D-Orn & DPG,PG,GL & Gal,Glc \\
\hline $\begin{array}{l}\text { A. arabinogalac- } \\
\text { tanolyticum }\end{array}$ & $14344^{\mathrm{T}}$ & 69.3 & MK-12,MK-13 & $\mathrm{B} 2 \beta$ & L-Hsr,D-Orn & DPG,PG,GL,PGL & Gal \\
\hline A. keratanolyticum & 13309 & 66.5 & MK-12,MK-13 & $\mathrm{B} 2 \alpha$ & L-Orn,D-Orn & DPG,PG,GL & Gal \\
\hline A. terrae & $15300^{\mathrm{T}}$ & 70.7 & MK-13,MK-14 & $\mathrm{B} 2 \boldsymbol{\beta}$ & L-Hsr,D-Orn & DPG,PG,GL,PGLs & Rha,Gal,Glc \\
\hline A. terrae & 15301 & 69.6 & MK-13,MK-14 & $\mathrm{B} 2 \beta$ & L-Hsr,D-Orn & DPG,PG,GL,PGLs & Rha,Gal,Glc \\
\hline $\begin{array}{l}\text { A. trichotheceno- } \\
\text { lyticum }\end{array}$ & $15077^{\mathrm{T}}$ & 69.0 & MK-12,MK-13 & $\mathrm{B} 2 \beta$ & L-Hsr,D-Orn & DPG,PG,GL & Gal,Glc \\
\hline A. luteolum & $15074^{\mathrm{T}}$ & 70.6 & MK-12 & $B 2 \beta$ & L-Hsr,D-Orn & DPG,PG,GL & Rha,Gal \\
\hline A. schleiferi & $15075^{\mathrm{T}}$ & 66.9 & MK-11,MK-12 & $\mathrm{B} 2 \beta$ & L-Hsr,D-Orn + D-Hyo & DPG,PG,GL & 6dTal,Man,Gal \\
\hline A. schleiferi & 15076 & 68.0 & MK-11,MK-12,MK-10 & $\mathrm{B} 2 \beta$ & L-Hsr,D-Orn + D-Hyo & DPG,PG,GL & 6dTal,Man,Gal \\
\hline
\end{tabular}

${ }^{a}$ Data for the type strains of $A$. liquefaciens, $A$. flavescens, $A$. terregens, $A$. saperdae, $A$. barkeri, and $A$. testaceum are from reference 2 . The major cellular fatty acids of all strains are 12-methyltetradecanoic acid and 14-methylhexadecanoic acid. All strains contained cell wall glycolyl groups, and none contained mycolic acids.

${ }_{b}^{b}$ L-Hsr, L-homoserine; D-Orn, D-ornithine; D-Hyo, D-hydroxyornithine.

${ }^{c}$ DPG, diphosphatidylglycerol; PG, phosphatidylglycerol; GL, glycolipid; PGL, phosphoglycolipid; PGLs, phosphoglycolipids.

${ }^{d}$ Rha, rhamnose; Gal, galactose; Glc, glucose; Man, mannose; 6dTal, 6-deoxytalose.

tion, all strains except IFO $3751^{\mathrm{T}}$ and IFO 3752 contained a small amount of L-lysine. Strains IFO $15075^{\mathrm{T}}$ and IFO 15076 contained equal amounts of D-ornithine and D-hydroxyornithine, as noted previously by Schleifer et al. (21).

The peptidoglycan studies of Schleifer and Kandler (22) showed that members of the genus Aureobacterium contained a B2 $\beta$ type of peptidoglycan (Fig. 1B). All of the test strains except strain IFO $13309^{\mathrm{T}}$ contained the B2 $\beta$ type of peptidoglycan; an examination of the primary structure of the murein of strain IFO $13309^{\mathrm{T}}$ indicated that its peptidoglycan type was B2 $\alpha$ (Fig. 1A).

All strains contained high levels of glycolate in the glycan moiety of the cell walls, which suggests that the muramic acid occurs in the $\mathrm{N}$-glycolyl form rather than the more common $\mathrm{N}$-acetyl form. The cell wall sugars rhamnose, 6-deoxytalose, mannose, galactose, and glucose were detected in various combinations (Table 3 ).

All of the strains produced very similar fatty acid profiles consisting primarily of anteiso-methyl branched acids, anteiso- $\mathrm{C}_{15: 0}$, and anteiso- $\mathrm{C}_{17: 0}$. Mycolic acid was not present in any of the strains. All of the strains contained long unsaturated menaquinones (10 to 14 isoprene units) (Table 4).

The polar lipids diphosphatidylglycerol and phosphatidylglycerol and an unidentified glycolipid were detected in the extracts of all strains. In addition, strains IFO $14344^{\mathrm{T}}$, IFO $15300^{\mathrm{T}}$, and IFO 15301 contained more than one unidentified glycolipid (Table 3 and Fig. 2).

All of the strains had DNA base compositions in the range from 66.5 to $70.7 \mathrm{~mol} \% \mathrm{G}+\mathrm{C}$ (Table 3).

On the basis of chemical characteristics, all of the strains except IFO $13309^{\mathbf{T}}$ were identified as members of the genus Aureobacterium and could be differentiated from the genera Curtobacterium and Microbacterium and all other coryneform genera described previously (Table 5). Strain IFO
$13309^{\mathrm{T}}$ differed from the members of the genus Aureobacterium in that it had a $\mathrm{B} 2 \alpha$ type of peptidoglycan, but its menaquinone composition, cellular fatty acid profile, and phospholipid pattern and the presence of a glycolyl residue in its muramic acid are typical of members of the genus Aureobacterium. This strain shows some resemblance to members of the genus Curtobacterium since glycine is not present in its cell wall but differs from Curtobacterium strains by its lack of L-homoserine, by its acyl type of muramic acid, and in its menaquinone system. Therefore, the possibility that it belongs to the genus Curtobacterium can be excluded, and we concluded that strain IFO $13309^{\mathrm{T}}$ should be included in the genus Aureobacterium.

Hensel (6) described coryneform strain S4 (= DSM 20620) which had a new murein type (type $B 2 \alpha$ ); this organism is somewhat similar to our strain IFO $13309^{\mathrm{T}}$ but differs in having glycine in the interpeptide bridge. Our results suggest that strain S4 may also belong in the genus Aureobacterium.

DNA-DNA hybridization. On the basis of DNA-DNA hybridization values (Table 6), the test strains could be separated into seven distinct DNA relatedness groups. High DNA relatedness values $(>70 \%)$ were obtained between IFO $3751^{\mathrm{T}}$ and IFO 3752 , between IFO 15300 and IFO 15301, and between IFO $15075^{\mathrm{T}}$ and IFO 15076. Strains IFO 15302 and IFO 15303 produced high reassociation values with $A$. testaceum IFO $12675^{\mathrm{T}}$.

Species differentiation. Differential characteristics for the seven DNA relatedness groups and the six previously described species of the genus Aureobacterium are summarized in Table 2. Strains IFO 15302 and IFO 15303 had the same phenotypic characteristics as $A$. testaceum and exhibited high levels of DNA relatedness (Table 6) with that species. Therefore, these strains were identified as members of $A$. testaceum.

The cell walls of members of the genus Aureobacterium 

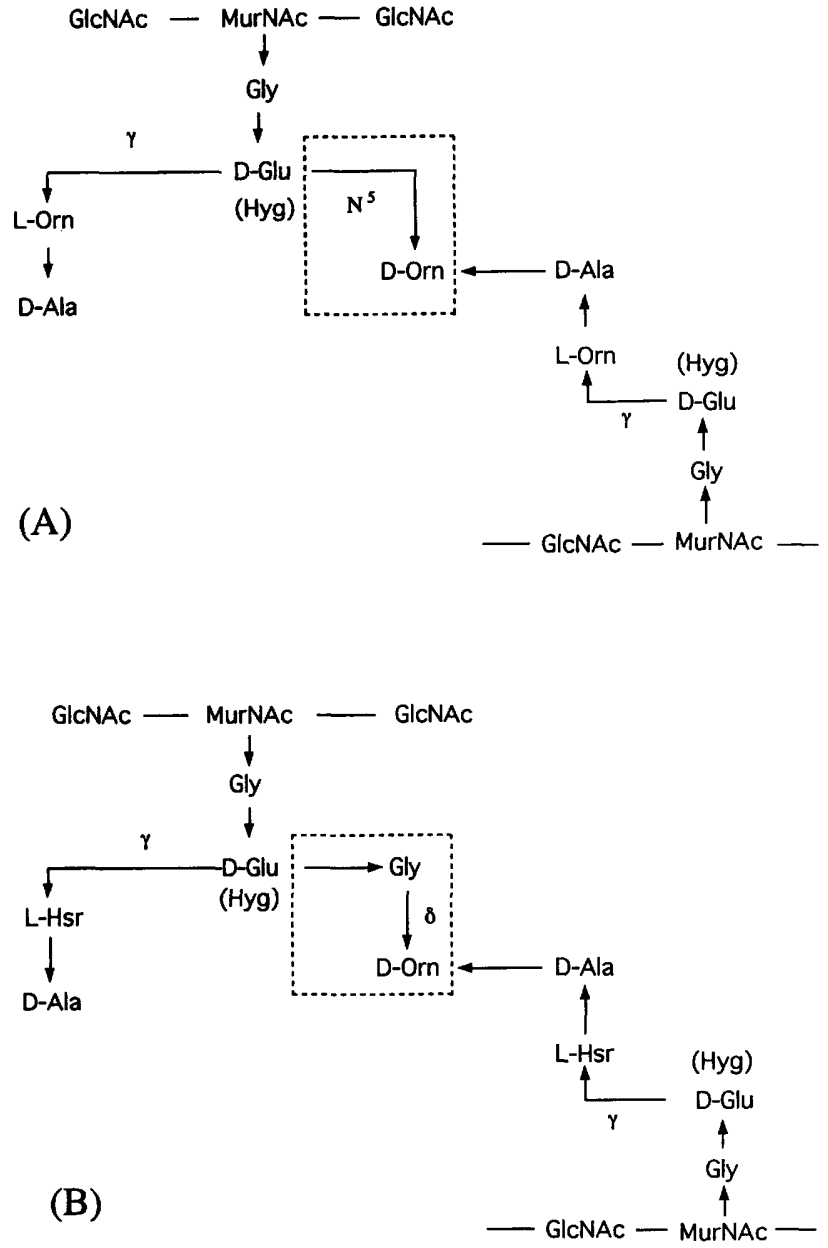

FIG. 1. Fragments of proposed primary structures of the peptidoglycans of $A$. keratanolyticum IFO $13309^{\mathrm{T}}$ (A) and $A$. liquefaciens (B). The structure of $A$. liquefaciens peptidoglycan is based on the data of Schleifer (20). Abbreviations: Gly, glycine; D-Glu, D-glutamic acid; D-Orn, D-ornithine; D-Ala, D-alanine; L-Orn, L-ornithine; Hyg, 3-hydroxyglutamic acid; L-Hsr, L-homoserine; GlcNAc; $N$-acetylglucosamine; MurNAc, $N$-acetylmuramic acid. The interpeptide bridge is enclosed by a dashed line.

contain a variety of sugars, including rhamnose, 6-deoxytalose, mannose, galactose, and glucose (Table 3). The strains in each DNA hybridization group contained the same combination of sugars in their cell walls. Thus, the cell wall sugar patterns were characteristic for the species in this genus.

The genus Aureobacterium was established by Collins et al. (2). It is characterized by the presence of $D$-ornithine in the cell wall (B2 $\beta$ type of peptidoglycan) with a glycine in the interpeptide bridge, $\mathrm{N}$-glycolyl residues in the cell wall, MK-11 to MK-14 isoprenoid quinones, $G+C$ values of 66 to $69 \mathrm{~mol} \%$, and slow and weak production of acid from sugars. On the basis of biochemical and chemical criteria, seven DNA hybridization groups can be distinguished readily from the previously described species of the genus Aureobacterium and in our opinion warrant new taxa. Therefore, we formally propose that the strains of these groups should be classified in the genus Aureobacterium as follows: Aureobacterium esteraromaticum comb. nov. for strains IFO $3751^{\mathrm{T}}$ and IFO 3752, Aureobacterium arabinogalactanolyticum sp. nov. for strain IFO $14344^{\mathrm{T}}$, Aureobacterium kera-
TABLE 4. Menaquinone compositions of the test strains

\begin{tabular}{|c|c|c|c|c|c|c|c|c|}
\hline \multirow[t]{2}{*}{ Species } & \multirow[t]{2}{*}{$\begin{array}{c}\text { Strain } \\
\text { (IFO no.) }\end{array}$} & \multicolumn{7}{|c|}{$\begin{array}{l}\% \text { of menaquinones with } \\
\text { the following no. } \\
\text { of isoprene units: }\end{array}$} \\
\hline & & 9 & 10 & 11 & 12 & 13 & 14 & 15 \\
\hline A. liquefaciens & $15037^{\mathrm{T}}$ & & 15 & 40 & 43 & 2 & & \\
\hline A. flavescens & $15039^{\mathrm{T}}$ & & & & 7 & 40 & 48 & 5 \\
\hline A. terregens & $12961^{\mathrm{T}}$ & & & 4 & 34 & 49 & 12 & \\
\hline A. saperdae & $15038^{\mathrm{T}}$ & & 5 & 28 & 60 & 7 & & \\
\hline A. barkeri & $15036^{\mathrm{T}}$ & & 9 & 51 & 38 & 2 & & \\
\hline A. testaceum & $12675^{\mathrm{T}}$ & 8 & 13 & 63 & 15 & 1 & & \\
\hline A. testaceum & 15302 & & 20 & 71 & 9 & & & \\
\hline A. testaceum & 15303 & & 16 & 72 & 12 & & & \\
\hline A. esteraromaticum & $3751^{\mathrm{T}}$ & & & 1 & 61 & 39 & & \\
\hline A. esteraromaticum & 3752 & & & 6 & 58 & 36 & & \\
\hline A. arabinogalactanolyticum & $14344^{\mathrm{T}}$ & & 2 & 7 & 60 & 30 & 1 & \\
\hline A. keratanolyticum & $13309^{\mathrm{T}}$ & & 8 & 8 & 41 & 42 & 2 & \\
\hline A. terrae & $15300^{\mathrm{T}}$ & & & & 7 & 64 & 28 & 1 \\
\hline A. terrae & 15301 & & & & 5 & 56 & 37 & 3 \\
\hline A. trichothecenolyticum & $15077^{\mathrm{T}}$ & & & & 23 & 60 & 17 & \\
\hline A. luteolum & $15074^{\mathrm{T}}$ & & & 19 & 64 & 17 & & \\
\hline A. schleiferi & $15075^{\mathrm{T}}$ & & 10 & 56 & 32 & & & \\
\hline A. schleiferi & 15076 & & 20 & 60 & 20 & & & \\
\hline
\end{tabular}

tanolyticum sp. nov. for strain IFO $13309^{\mathrm{T}}$, Aureobacterium luteolum sp. nov. for strain IFO $15074^{\mathrm{T}}$, Aureobacterium schleiferi sp. nov. for strains IFO $15075^{\mathrm{T}}$ and IFO 15076 , Aureobacterium terrae sp. nov. for strains IFO $15300^{\mathrm{T}}$ and IFO 15301, and Aureobacterium trichothecenolyticum sp. nov. for strain IFO $15077^{\mathrm{T}}$.

An emended description of the genus Aureobacterium and descriptions of the new combination and new species are given below.

Emended description of the genus Aureobacterium Collins, Jones, Keddie, Kroppenstedt, and Schleifer. Aureobacterium (Aur.e.o.bac.te'ri.um. L. adj. aureus, golden; Gr. neut. n. bakterion, a small rod; M. L. neut. n. Aureobacterium, small golden rod). The salient characteristics of this genus, based on the description of Collins et al. (2) and our own observations, are as follows. In young cultures, small irregular rods occur; some cells are arranged at an angle, forming $\mathrm{V}$ shapes. In older cultures (ca. 3 to 7 days) the rods are shorter, but a marked rod-coccus cycle (characteristic of the genus Arthrobacter) is not observed. Primary branching is uncommon. The rods are gram positive and not acid fast; metachromatic granules are not formed; endospores are not formed. Growth occurs on suitable solid media in air. Growth is inhibited by $6.5 \% \mathrm{NaCl}$. Growth occurs at ca. 10 to $40^{\circ} \mathrm{C}$; the optimum temperature is ca. 25 to $30^{\circ} \mathrm{C}$. Obligately aerobic. Slow and weak oxidative production of acid from some carbohydrates occurs. Nutritionally exacting. Some organic acids are utilized. Catalase positive. Oxidase negative. Indole negative. Esculin is hydrolyzed. Noncellulolytic.

The cell wall peptidoglycan is based on D-ornithine or D-hydroxyornithine (type B2 $\beta$ of Schleifer and Kandler [22]) ([L-Hsr]-D-Glu-Gly-D-Orn) or on D- and L-ornithine (type B2 $\alpha$ of Schleifer and Kandler [22]) ([L-Orn]-D-Glu-D-Orn). The glycan moiety of peptidoglycan contains glycolyl and acetyl residues. Contains no mycolic acids. The nonhydroxylated fatty acids are predominantly anteiso- and iso-methyl branched-chain acids; small amounts of straight-chain saturated acids and traces of monounsaturated acids may be present. Menaquinones are the sole respiratory quinones. The major menaquinone isoprenologs contain various num- 

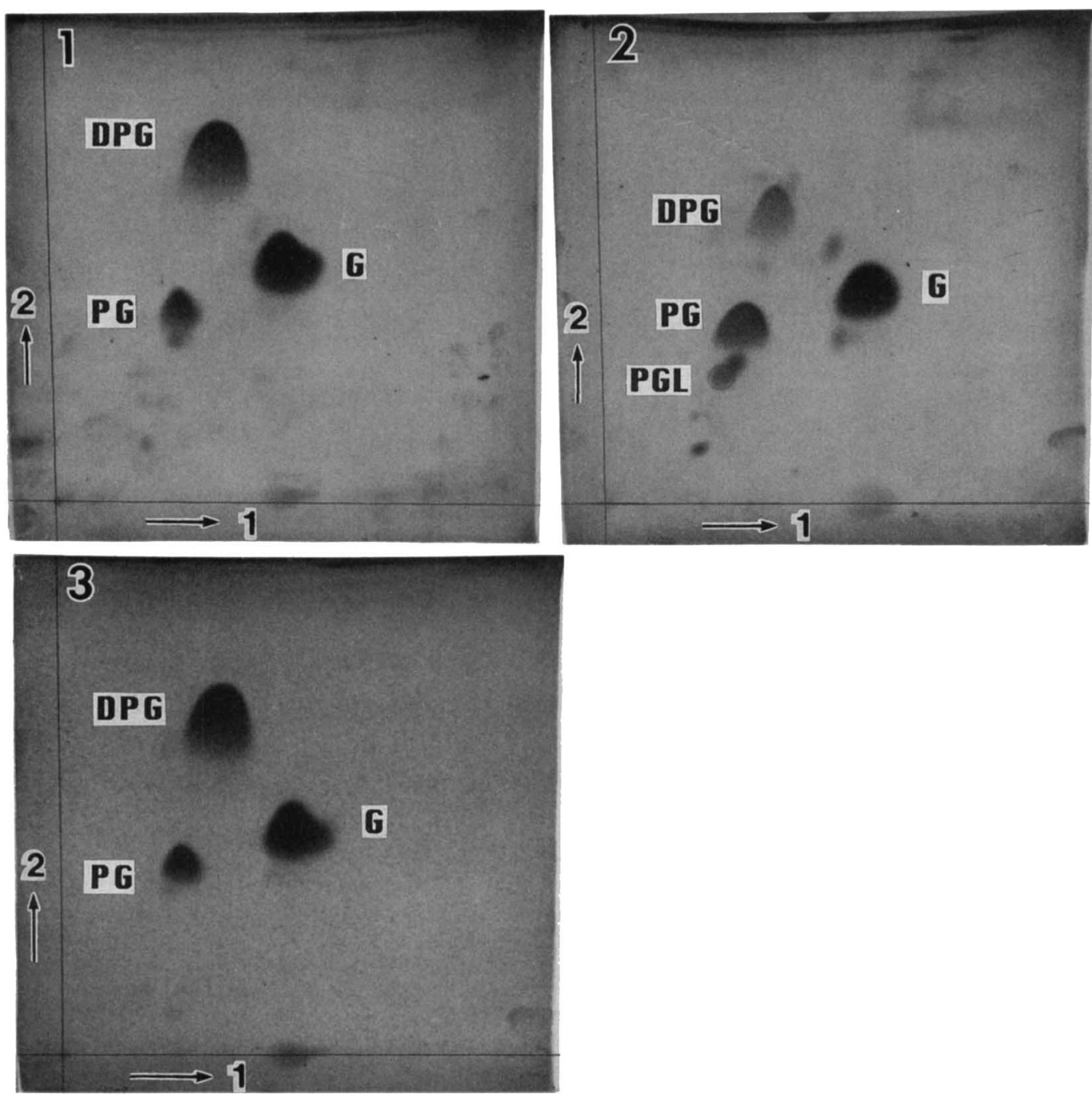

FIG. 2. Two-dimensional thin-layer chromatograms of polar lipids from $A$. liquefaciens IFO $15037^{\mathrm{T}}$ (panel 1), A. arabinogalactanolyticum IFO $14344^{\mathrm{T}}$ (panel 2), and $A$. keratanolyticum IFO $13309^{\mathrm{T}}$ (panel 3).

bers of isoprene units $(10,11,12,13$, and 14 isoprene units). The polar lipids are diphosphatidylglycerol, phosphatidylglycerol, and unidentified glycolipids. DNA base compositions range from 65 to $76 \mathrm{~mol} \% \mathrm{G}+\mathrm{C}(8)$.

The type species is Aureobacterium liquefaciens.

Description of Aureobacterium esteraromaticum (Omelianski 1923) comb. nov. Aureobacterium esteraromaticum (es.ter. a.ro.ma'ti.cum. German n. ester, ester; Gr. adj. aromatikos, sweet smelling; M. L. neut. adj. esteraromaticum, sweet smelling because of esters). Gram-positive motile rods. The motile cells have lateral flagella. Colonies are 1 to $3 \mathrm{~mm}$ in diameter, circular, low convex with entire margins, opaque, and moist. A yellow pigment is produced. Many cells are arranged at an angle, forming $\mathrm{V}$ shapes. The optimum growth temperature is ca. $28^{\circ} \mathrm{C}$. No growth occurs in the presence of $2.0 \% \mathrm{NaCl}$. The oxidation-fermentation test is oxidative.

Acetate, malate, succinate, fumarate, lactate, propionate, and hippurate are assimilated, but formate, citrate, and oxalate are assimilated weakly or not assimilated. Starch, Tween 40 , Tween 60 , and Tween 80 are hydrolyzed. Gelatin is not hydrolyzed. Nitrate is not reduced. Voges-Proskauer negative. Methyl red positive. Urease negative. $\mathrm{H}_{2} \mathrm{~S}$ is produced. Arginine dihydrolase is not produced.

The cell wall peptidoglycan contains ornithine, homoserine, glutamate plus hydroxyglutamate, glycine, and alanine (molar ratio, ca. 1:1:1:2:1; variation B2 $\beta$ of Schleifer and Kandler [22]). The cell wall sugars are galactose and glucose. The major cellular fatty acids are anteiso- and iso-methyl branched acids, anteiso- $C_{15: 0}$, and anteiso- $C_{17: 0}$. Unsaturated menaquinones with 12 and 13 isoprene units are present. The polar lipids are diphosphatidylglycerol, phosphatidylglycerol, and an unidentified glycolipid. The DNA base composition of the type strain is $68.8 \mathrm{~mol} \% \mathrm{G}+\mathrm{C}$. Source: soil $(18,24)$.

The type strain is IFO 3751 (= ATCC 8091) $(1,18)$.

Flavobacterium esteraromaticum (18) is the basonym of this species. "Flavobacterium suaveolens" IFO 3752 (= ATCC 958) $(24,30)$ is included in this species.

Description of Aureobacterium arabinogalactanolyticum sp. nov. Aureobacterium arabinogalactanolyticum (a.ra.bi.no. ga.lac.ta.no.ly'ti.cum. Engl. n. arabinogalactan, polysaccharide produced by the bacterium Mycobacterium tuberculosis; Gr. adj. lyticum, dissolving; arabinogalac- 
TABLE 5. Distinguishing chemotaxonomic characteristics of coryneform taxa

\begin{tabular}{|c|c|c|c|c|c|c|c|}
\hline Taxon & $\begin{array}{l}\text { Wall di- } \\
\text { amino acid }\end{array}$ & $\begin{array}{l}\text { Murein } \\
\text { type }^{b}\end{array}$ & $\begin{array}{l}\mathrm{G}+\mathrm{C} \\
\text { content } \\
(\mathrm{mol} \%)\end{array}$ & $\begin{array}{l}\text { Mycolic } \\
\text { acids }\end{array}$ & $\begin{array}{l}\text { Fatty acid } \\
\text { types }\end{array}$ & Major menaquinone(s) & Polar lipids ${ }^{d, e}$ \\
\hline Agromyces & L-DAB & $\mathbf{B} 2 \gamma$ & $71-76$ & - & $\mathrm{S}, \mathrm{A}, \mathrm{I}$ & MK-11, MK-12, MK-13 & DPG, PG, GL \\
\hline Arcanobacterium & Lys & A & $48-52$ & - & S, U & MK-9( $\left.\mathbf{H}_{4}\right)$ & ND \\
\hline $\begin{array}{l}\text { Arthrobacter (globiformis } \\
\text { group) }\end{array}$ & L-Lys & $\mathrm{A} 3 \alpha$ & $59-69$ & - & $\mathrm{S}, \mathrm{A}, \mathrm{I}$ & MK- $9\left(\mathrm{H}_{2}\right)$ & DPG, PG, (PI), GL \\
\hline $\begin{array}{l}\text { Arthrobacter (nicotianae } \\
\text { group) }\end{array}$ & L-Lys & $\mathrm{A} 4 \alpha$ & $59-69$ & - & $\mathbf{S}, \mathbf{A}, \mathbf{I}$ & MK-8, MK-9 & DPG, PG, (PI), GL \\
\hline Aureobacterium & D-Orn & $\mathrm{B} 2 \beta, \mathrm{B} 2 \alpha$ & $67-70$ & - & $\mathrm{S}, \mathrm{A}, \mathrm{I}$ & $\begin{array}{l}\text { MK-11, MK-12, MK-13, } \\
\text { MK-14 }\end{array}$ & DPG, PG, GL \\
\hline Brachybacterium & meso-DAP & $\mathrm{A} 4 \gamma$ & $68-72$ & - & S, A, I & MK-7 & DPG, PG, GL \\
\hline Brevibacterium & meso-DAP & $\mathrm{Al} \gamma$ & $60-67$ & - & S, A, I & $\mathrm{MK}-8\left(\mathrm{H}_{2}\right), \mathrm{MK}-7\left(\mathrm{H}_{2}\right)$ & DPG, PG, (PI), GL \\
\hline Cellulomonas & L-Orn & $\mathrm{A} 4 \hat{\beta}, \mathrm{A} 4 \alpha$ & $71-76$ & - & $\mathrm{S}, \mathrm{A}, \mathrm{I}$ & MK $-9\left(\mathrm{H}_{4}\right)$ & DPG, PI, PGL \\
\hline Corynebacterium & meso-DAP & $\mathrm{Al} \gamma$ & $51-65$ & + & $\mathrm{S}, \mathrm{U},(\mathrm{T})$ & MK-9(H $\left.{ }_{2}\right)$, MK-8( $\left.\mathrm{H}_{2}\right)$ & DPG, PI, PIDM, (PG), (GL) \\
\hline Clavibacter & L-DAB & $\mathrm{B} 2 \gamma$ & $67-78$ & - & $\mathrm{S}, \mathrm{A}, \mathrm{I}$ & MK-10, MK-9 & DPG, PG, GL \\
\hline Curtobacterium & D-Orn & $\mathbf{B} 2 \beta$ & $68-75$ & - & S, A, I & MK-9 & DPG, PG, GLs \\
\hline Exiguobacterium & Lys & A & $53-56$ & - & $\mathrm{S}, \mathrm{A}, \mathrm{I}, \mathrm{U}$ & MK-7 & DPG, PG, PE \\
\hline Jonesia & Lys & A & $58-59$ & - & $\mathrm{S}, \mathrm{A}, \mathrm{I}$ & MK-9 & DPG, PI, PGL \\
\hline Microbacterium & L-Lys & $\mathrm{B} 1 \alpha, \mathrm{B} 1 \beta$ & $69-75$ & - & S, A, I & MK-11, MK-12 & DPG, PG, GL, (PGL) \\
\hline Nocardioides & LL-DAP & $\mathrm{A} 3 \gamma$ & $69-72$ & - & $\begin{array}{l}\mathrm{S}, \mathrm{A}, \mathrm{I}, \mathrm{U}, \mathrm{T}, \\
2-\mathrm{OH}\end{array}$ & 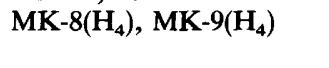 & DPG, PG, OH-PG \\
\hline Terrabacter & LL-DAP & $\mathrm{A} 3 \gamma$ & $69-72$ & - & $\mathrm{S}, \mathrm{A}, \mathrm{I}, \mathrm{U}$ & MK-8 $\left(\mathrm{H}_{4}\right)$ & DPG, PE, PL, PGL \\
\hline Aeromicrobium & LL-DAP & $\mathrm{A} 3 \gamma$ & $69-72$ & - & & & \\
\hline Rarobacter & L-Orn & A & $65-66$ & - & S, A, I & MK-9 & ND \\
\hline Renibacterium & L-Lys & $\mathrm{A} 3 \alpha$ & $52-54$ & - & S, A, I & MK-9, MK-10 & DPG, GL \\
\hline Rubrobacter & L-Lys & $\mathrm{A} 3 \alpha$ & 68 & - & $12-\mathrm{H}, \mathrm{A}, 2-\mathrm{OH}$ & MK-8 & DPG, PG, PL, PGL, GL \\
\hline
\end{tabular}

a L-DAB, L-diaminobutyric acid; Lys, lysine; L-Lys, L-lysine; D-Orn, D-ornithine; meso-DAP, meso-diaminopimelic acid; L-Orn, L-ornithine; LL-DAP, LL-diaminopimelic acid.

${ }^{b}$ Murein type as described by Schleifer and Kandler (22).

c S, straight-chain saturated; A, anteiso-methyl branched; I, iso-methyl branched; U, monounsaturated; T, tuberculostearic acid; 12 -H, 12 -methylhexadecanoic acid; 2-OH, 2-hydroxylated fatty acids.

d Parentheses indicate that a compound may or may not be present.

e DPG, diphosphatidylglycerol; PG, phosphatidylglycerol; GL, glycolipid; PI, phosphatidylinositol; PIDM, phosphatidylinositol dimannoside; GLs, glycolipids; PE, phosphatidylethanolamine; OH-PG, 2-hydroxy fatty acid containing phosphatidylglycerol; PL, phospholipid; PGL, phosphoglycolipid; ND, not determined.

tanolyticum, arabinogalactan dissolving.) Gram-positive, nonmotile rods. Colonies are 1 to $3 \mathrm{~mm}$ in diameter, circular, low convex with entire margins, opaque, and moist. No pigment is produced. Many cells are arranged at an angle, forming $\mathrm{V}$ shapes. The optimum growth temperature is ca. $28^{\circ} \mathrm{C}$. Growth occurs in the presence of $2.0 \% \mathrm{NaCl}$. The oxidation-fermentation test is oxidative.

Acetate, malate, succinate, oxalate, fumarate, lactate, propionate, and hippurate are assimilated, and formate and citrate are weakly assimilated. Gelatin, starch, Tween 60 , and Tween 80 are hydrolyzed. Tween 20 and Tween 40 are not hydrolyzed. Nitrate is not reduced. Voges-Proskauer negative. Methyl red positive. Urease positive. $\mathrm{H}_{2} \mathrm{~S}$ is produced. Arginine dihydrolase is produced.

The cell wall peptidoglycan contains ornithine, homoserine, glutamate plus hydroxyglutamate, glycine, alanine, and a small amount of lysine (molar ratio, ca. 1:1:1:2:1:0.2; variant B2 $\beta$ of Schleifer and Kandler [22]). The cell wall sugar is galactose. The major cellular fatty acids are anteisoand iso-methyl branched acids, anteiso- $\mathrm{C}_{15: 0}$, and anteiso$C_{17: 0}$. Unsaturated menaquinones with 12 and 13 isoprene units are present. The polar lipids are diphosphatidylglycerol, phosphatidylglycerol, an unidentified glycolipid, and phosphoglycolipid. The $\mathrm{G}+\mathrm{C}$ content of the DNA of the type strain is $69.3 \mathrm{~mol} \%$. Produces $\alpha$-D-arabinofuranosidase $(9,14)$. Source: soil $(9)$.

The type strain is IFO 14344.

Description of Aureobacterium keratanolyticum sp. nov. Aureobacterium keratanolyticum (ker.a.ta.no.ly'ti.cum.
Engl. n. keratan, sulfur-containing polysaccharide produced by mammals; Gr. adj. lyticum, dissolving; keratanolyticum, keratan dissolving). Gram-positive, motile rods. Colonies are 1 to $3 \mathrm{~mm}$ in diameter, circular, low convex with entire margins, opaque, and moist. A yellow pigment is produced. Many cells are arranged at an angle, forming V shapes. The optimum growth temperature is ca. $28^{\circ} \mathrm{C}$. Growth occurs in the presence of $2.0 \% \mathrm{NaCl}$. The oxidation-fermentation test is oxidative.

Acetate, lactate, malate, succinate, fumarate, propionate, oxalate, and hippurate are assimilated, but citrate and formate are assimilated weakly or not assimilated. Esculin and gelatin are hydrolyzed. Starch, Tween 20 , Tween 40 , Tween 60 , and Tween 80 are not hydrolyzed. Urease negative. Nitrate is reduced. Voges-Proskauer negative. Methyl red positive. $\mathrm{H}_{2} \mathrm{~S}$ is produced. Arginine dihydrolase is produced.

The cell wall peptidoglycan contains ornithine but not homoserine; the cell wall amino acids include ornithine, glutamate plus hydroxyglutamate, glycine, alanine, and a small amount of glycine (molar ratio, ca. 2:1:1:1:1:0.5; variation B2 $\alpha$ of Schleifer and Kandler [22]). The cell wall sugar is galactose. The major cellular fatty acids are anteisoand iso-methyl branched acids, anteiso- $\mathrm{C}_{15: 0}$, and anteiso$\mathrm{C}_{17: 0}$. Unsaturated menaquinones with 12 and 13 isoprene units are present. The polar lipids are diphosphatidylglycerol, phosphatidylglycerol, and an unidentified glycolipid. The $\mathrm{G}+\mathrm{C}$ content of the DNA of the type strain is 66.5 mol\%. Produces keratan sulfate endo- $\beta$-galactosidase (EC 3.2.1.103) $(16,17)$. Source: soil (16). 
TABLE 6. Levels of DNA relatedness between test strains and the type strains of members of the genus Aureobacterium

\begin{tabular}{|c|c|c|c|c|c|c|c|c|c|c|c|c|c|c|c|c|}
\hline \multirow[b]{2}{*}{ Species } & \multirow[b]{2}{*}{$\begin{array}{c}\text { Strain } \\
\text { (IFO no.) }\end{array}$} & \multicolumn{15}{|c|}{$\%$ of DNA-DNA reassociation with: } \\
\hline & & 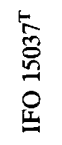 & 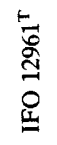 & 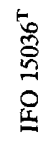 & 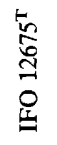 & 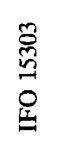 & 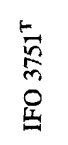 & 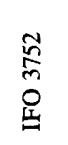 & 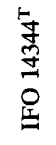 & 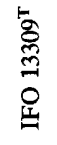 & 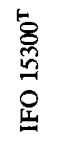 & 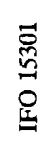 & 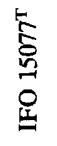 & 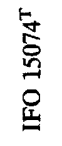 & 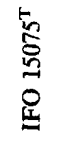 & 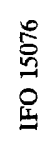 \\
\hline A. liquefaciens & $15037^{\mathrm{T}}$ & 100 & 9 & 13 & 16 & 14 & 16 & 22 & 5 & 17 & 1 & 12 & 2 & 12 & 10 & 11 \\
\hline A. flavescens & $15039^{\mathrm{T}}$ & 16 & 13 & 9 & 9 & 19 & 18 & 22 & 18 & 10 & 8 & 26 & 10 & 12 & 8 & 23 \\
\hline A. terregens & $12961^{\mathrm{T}}$ & 28 & 100 & 38 & 19 & 21 & 5 & 15 & 20 & 20 & 4 & 13 & 5 & 10 & 11 & 2 \\
\hline A. saperdae & $15038^{\mathrm{T}}$ & 2 & 9 & 15 & 11 & 29 & 11 & 25 & 8 & 17 & 3 & 5 & 22 & 13 & 7 & 3 \\
\hline A. barkeri & $15036^{T}$ & 1 & 18 & 100 & 17 & 17 & 6 & 23 & 19 & 13 & 24 & 14 & 3 & 10 & 7 & 10 \\
\hline A. testaceum & $12675^{\mathrm{T}}$ & 3 & 33 & 41 & 100 & 87 & 13 & 11 & 8 & 12 & 4 & 14 & 8 & 8 & 9 & 8 \\
\hline A. testaceum & 15302 & 16 & 20 & 19 & 75 & 92 & 28 & 10 & 17 & 17 & 3 & 16 & 7 & 11 & 8 & 13 \\
\hline A. testaceum & 15303 & 1 & 21 & 8 & 87 & 100 & 15 & 17 & 14 & 10 & 2 & 13 & 21 & 12 & 8 & 7 \\
\hline A. esteraromaticum & $3751^{\mathrm{T}}$ & 5 & 33 & 7 & 2 & 9 & 100 & 99 & 10 & 21 & 8 & 7 & 13 & 10 & 6 & 2 \\
\hline A. esteraromaticum & 3752 & 4 & 13 & 8 & 3 & 6 & 96 & 100 & 11 & 14 & 4 & 6 & 11 & 32 & 6 & 0 \\
\hline A. arabinogalactanolyticum & $14344^{\mathrm{T}}$ & 7 & 9 & 12 & 10 & 1 & 20 & 3 & 100 & 32 & 9 & 11 & 4 & 10 & 33 & 7 \\
\hline A. keratanolyticum & $13309^{\mathrm{T}}$ & 13 & 29 & 3 & 5 & 10 & 17 & 1 & 5 & 100 & 15 & 7 & 5 & 17 & 25 & 5 \\
\hline A. terrae & $15300^{\mathrm{T}}$ & 7 & 16 & 23 & 3 & 16 & 15 & 13 & 26 & 12 & 100 & 89 & 13 & 16 & 10 & 13 \\
\hline A. terrae & 15301 & 30 & 25 & 59 & 11 & 10 & 28 & 15 & 24 & 14 & 84 & 100 & 17 & 22 & 9 & 15 \\
\hline A. trichothecenolyticum & $15077^{\mathrm{T}}$ & 2 & 37 & 13 & 9 & 6 & 18 & 13 & 8 & 9 & 5 & 14 & 100 & 9 & 12 & 5 \\
\hline A. luteolum & $15074^{\mathrm{T}}$ & 1 & 37 & 2 & 11 & 1 & 22 & 4 & 18 & 8 & 6 & 6 & 8 & 100 & 8 & 10 \\
\hline A. schleiferi & $15075^{\mathrm{T}}$ & 0 & 30 & 0 & 5 & 1 & 7 & 3 & 15 & 16 & 3 & 1 & 4 & 10 & 100 & 90 \\
\hline A. schleiferi & 15076 & 1 & 23 & 6 & 7 & 3 & 7 & 12 & 9 & 17 & 3 & 7 & 3 & 13 & 86 & 100 \\
\hline
\end{tabular}

The type strain is IFO 13309.

Description of Aureobacterium terrae sp. nov. Aureobacterium terrae (ter'rae. L. n. terra, soil; M. L. gen. n. terrae, of soil). Gram-positive, nonmotile rods. Colonies are 1 to $3 \mathrm{~mm}$ in diameter, circular, low convex with entire margins, opaque, and moist. A yellow pigment is produced. In young cultures, small irregular rods are formed. Many cells are arranged at an angle, forming $\mathrm{V}$ shapes. The optimum growth temperature is ca. $28^{\circ} \mathrm{C}$. Growth occurs in the presence of $2.0 \% \mathrm{NaCl}$. The oxidation-fermentation test is oxidative.

Acetate, fumarate, and lactate are assimilated, and formate, citrate, malate, succinate, propionate, and hippurate are assimilated weakly or not assimilated. Gelatin, starch, Tween 40, Tween 60, and Tween 80 are hydrolyzed. Nitrate is reduced. Voges-Proskauer and methyl red negative. Urease positive. $\mathrm{H}_{2} \mathrm{~S}$ is formed. Arginine dihydrolase is not produced.

The cell wall peptidoglycan contains ornithine, homoserine, glutamate plus hydroxyglutamate, glycine, alanine, and a small amount of lysine (molar ratio, ca. 1:1:1:2:1:0.2; variation B2 $\alpha$ of Schleifer and Kandler [22]). The cell wall sugars are rhamnose, galactose, and glucose. The major cellular fatty acids are anteiso- and iso-methyl branched acids, anteiso- $C_{15: 0}$, and anteiso- $C_{17: 0}$. Unsaturated menaquinones with 13 and 14 isoprene units are present. The polar lipids are diphosphatidylglycerol, phosphatidylglycerol, and unidentified phosphoglycolipids. The $\mathrm{G}+\mathrm{C}$ content of the DNA of the type strain is $70.7 \mathrm{~mol} \%$. Source: soil.

The type strain is IFO 15300.

Description of Aureobacterium trichothecenolyticum sp. nov. Aureobacterium trichothecenolyticum (tri.cho.the.ce.no. ly'ti.cum. Engl. n. trichothecene, a mycotoxin produced by the fungus Trichothecium roseum; Gr. adj. lyticum, decomposing; trichothecenolyticum, trichothecene decomposing). Gram-positive, nonmotile rods. Colonies are 1 to $3 \mathrm{~mm}$ in diameter, circular, low convex with entire margins, opaque, and moist. A yellow pigment is produced. Many cells are arranged at an angle, forming $\mathrm{V}$ shapes. The optimum growth temperature is ca. $28^{\circ} \mathrm{C}$. Grows weakly in the presence of $2.0 \% \mathrm{NaCl}$. The oxidation-fermentation test is oxidative.

Acetate, malate, succinate, and fumarate are assimilated; formate, citrate, oxalate, lactate, propionate, and hippurate are not assimilated. Starch, Tween 20 , Tween 40, Tween 60 , and Tween 80 are hydrolyzed. Gelatin is not hydrolyzed. Nitrate is reduced. Voges-Proskauer and methyl red negative. Urease positive. $\mathrm{H}_{2} \mathrm{~S}$ is formed. Arginine dihydrolase is not formed.

The cell wall peptidoglycan contains ornithine, homoserine, glutamate plus hydroxyglutamate, glycine, alanine, and a small amount of lysine (molar ratio, ca. 1:1:1:2:1:0.4; variation $B 2 \alpha$ of Schleifer and Kandler [22]). The cell wall sugars are galactose and glucose. The major cellular fatty acids are anteiso- and iso-methyl branched acids, anteiso$C_{15: 0}$, and anteiso- $C_{17: 0}$. Unsaturated menaquinones with 12 and 13 isoprene units are present. The polar lipids are diphosphatidylglycerol, phosphatidylglycerol, and an unidentified glycolipid. The $\mathrm{G}+\mathrm{C}$ content of the DNA of the type strain is $69.0 \mathrm{~mol} \%$. Decomposes trichothecene mycotoxin $(8,15)$. Source: soil $(15)$.

The type strain is IFO 15077 (= JCM 1358).

Description of Aureobacterium luteolum sp. nov. Aureobacterium luteolum (lu.te.o'lum. L. adj. luteus, yellow; L. neut. adj. luteolum, yellowish) Gram-positive, nonmotile rods. Colonies are 1 to $3 \mathrm{~mm}$ in diameter, circular, low convex with entire margins, opaque, and moist. A yellow pigment is produced. Many cells are arranged at an angle, forming V shapes. The optimum growth temperature is ca. $28^{\circ} \mathrm{C}$. No growth occurs in the presence of $2.0 \% \mathrm{NaCl}$. The oxidationfermentation test is oxidative.

Acetate, malate, succinate, fumarate, lactate, propionate, and hippurate are assimilated; formate, citrate, and oxalate are assimilated weakly or not assimilated. Starch, Tween 20, Tween 40, Tween 60, Tween 80 , and gelatin are not hydrolyzed. Nitrate is reduced. Voges-Proskauer negative. Methyl red positive. Urease positive. $\mathrm{H}_{2} \mathrm{~S}$ is not formed. Arginine dihydrolase is not produced. 
The cell wall peptidoglycan contains ornithine, homoserine, glutamate plus hydroxyglutamate, glycine, alanine, and a small amount of lysine (molar ratio, ca. 1:1:1:2:1:0.5; variation B2 $\alpha$ of Schleifer and Kandler [22]). The cell wall sugars are rhamnose, galactose, and glucose. The major cellular fatty acids are anteiso- and iso-methyl branched acids, anteiso- $\mathrm{C}_{15: 0}$, and anteiso- $\mathrm{C}_{17: 0}$. Unsaturated menaquinones with 12 isoprene units are present. The polar lipids are diphosphatidylglycerol, phosphatidylglycerol, and an unidentified glycolipid. The G+C content of the DNA of the type strain is $70.6 \mathrm{~mol} \%$. Source: soil (27).

The type strain is IFO 15074 (= DSM 20143).

Description of Aureobacterium schleiferi sp. nov. Aureobacterium schleiferi (schlei'fer.i. L. gen. n. schleiferi, of Schleifer, referring to K. H. Schleifer, a German microbiologist who contributed to the elucidation of the primary structure of peptidoglycan and to taxonomic studies of the strains belonging to this species). Gram-positive, nonmotile rods. Colonies are 1 to $3 \mathrm{~mm}$ in diameter, circular, low convex with entire margins, opaque, and moist. A yellow pigment is produced. Many cells are arranged at an angle, forming V shapes. The optimum growth temperature is ca. $28^{\circ} \mathrm{C}$. Growth occurs in the presence of $2.0 \% \mathrm{NaCl}$. The oxidationfermentation test is oxidative.

Organic acids are not assimilated. Tween 40 is hydrolyzed. Starch and gelatin are not hydrolyzed. Nitrate is not reduced. Voges-Proskauer positive. Methyl red negative. Urease negative. $\mathrm{H}_{2} \mathrm{~S}$ is not produced. Arginine dihydrolase is produced weakly.

The cell wall peptidoglycan contains ornithine plus hydroxyornithine, homoserine, glutamate plus hydroxyglutamate, glycine, alanine, and a small amount of lysine (molar ratio, ca. 1:1:1:2:1:0.4 [21]; variation $B 2 \beta$ of Schleifer and Kandler [22]). The cell wall sugars are 6-deoxytalose, mannose, and galactose. The major cellular fatty acids are anteiso- and iso-methyl branched acids, anteiso- $\mathrm{C}_{15: 0}$, and anteiso- $\mathrm{C}_{17: 0}$. Unsaturated menaquinones with 11 and 12 isoprene units are present. The polar lipids are diphosphatidylglycerol, phosphatidylglycerol, and an unidentified glycolipid. The $\mathrm{G}+\mathrm{C}$ content of the DNA of the type strain is 66.9 mol\%. Source: soil (21).

The type strain is IFO 15075 (= DSM 20489).

\section{ACKNOWLEDGMENTS}

We thank Kazuo Komagata, Tokyo University of Agriculture, for valuable discussions and suggestions. We also thank Toru Hasegawa, Institute for Fermentation, Osaka, for support and discussions.

\section{REFERENCES}

1. Bergey, D. H., F. C. Harrison, R. S. Breed, B. W. Hammer, and F. M. Huntoon. 1930. Bergey's manual of determinative bacteriology, 3rd ed. The Williams and Wilkins Co., Baltimore.

2. Collins, M. D., D. Jones, R. M. Keddie, R. M. Kroppenstedt, and K. H. Schleifer. 1983. Classification of some coryneform bacteria in a new genus, Aureobacterium. Syst. Appl. Microbiol. 4:236-252.

3. Cowan, S. T., and K. J. Steel. 1965. Manual for the identification of medical bacteria. Cambridge University Press, London.

4. Ezaki, T., Y. Hashimoto, and E. Yabuuchi. 1989. Fluorometric deoxyribonucleic acid-deoxyribonucleic acid hybridization in microdilution wells as an alternative to membrane filter hybridization in which radioisotopes are used to determine genetic relatedness among bacterial strains. Int. J. Syst. Bacteriol. 39:224-229.

5. Harper, J. J., and G. H. G. Davis. 1979. Two-dimensional thin-layer chromatography for amino acid analysis of bacterial cell walls. Int. J. Syst. Bacteriol. 29:56-58.

6. Hensel, R. 1984. Three new murein types in coryneform bacteria isolated from activated sludge. Syst. Appl. Microbiol. 5:11-19.

7. Kandler, O., and H. König. 1978. Chemical composition of the peptidoglycan-free cell walls of methanogenic bacteria. Arch. Microbiol. 118:141-152.

8. Komagata, K., and K. Suzuki. 1986. Genus Aureobacterium Collins, Jones, Keddie, Kroppenstedt and Schleifer 1983, $672^{\text {VP }}$, p. 1323-1325. In P. H. A. Sneath, N. S. Mair, M. E. Sharpe, and J. G. Holt (ed.), Bergey's manual of systematic bacteriology, vol. 2. The Williams \& Wilkins Co., Baltimore.

9. Kotani, S., T. Kato, T. Matsubara, M. Sakagoshi, and Y. Hirachi. 1972. Inducible enzyme degrading serologically active polysaccharides from mycobacterial and corynebacterial cells. Biken J. 15:1-15.

10. Mesbah, M., U. Premachandran, and W. B. Whitman. 1989. Precise measurement of the $\mathrm{G}+\mathrm{C}$ content of deoxyribonucleic acid by high-performance liquid chromatography. Int. J. Syst. Bacteriol. 39:159-167.

11. Mikami, H., and Y. Ishida. 1983. Post-column fluorometric detection of reducing sugars in high-performance liquid chromatography using arginine. Bunseki Kagaku 32:E207-E210.

12. Minnikin, D. E., L. Alshamaony, and M. Goodfellow. 1975. Differentiation of Mycobacterium, Nocardia and related taxa by thin-layer chromatographic analysis of whole-organism methanolysates. J. Gen. Microbiol. 88:200-206.

13. Minnikin, D. E., M. D. Collins, and M. Goodfellow. 1979. Fatty acid and polar lipid composition in the classification of Cellulomonas, Oerskovia and related taxa. J. Appl. Bacteriol. 47:8795.

14. Misaki, A., I. Azuma, and Y. Yamamura. 1977. Structural and immunological studies on D-arabino-D-mannans and D-mannans of Mycobacterium tuberculosis and other Mycobacterium species. J. Biochem. 82:1759-1770.

15. Nakayama, K., A. Kato, Y. Ueno, Y. Minoda, and K. Komagata. 1980. Studies on the metabolism of trichothecene mycotoxins. II. Metabolism of T-2 toxin with the soil bacteria. Proc. Jpn. Assoc. Mycotoxicol. 12:30-32.

16. Nakazawa, K., N. Suzuki, and S. Suzuki. 1975. Sequential degradation of keratan sulfate by bacterial enzymes and purification of a sulfatase in the enzymatic system. J. Biol. Chem. 250:905-911.

17. Nakazawa, K., and S. Suzuki. 1975. Purification of keratan sulfate-endogalactosidase and its action on keratan sulfates of different origin. J. Biol. Chem. 250:912-917.

18. Omelianski, V. L. 1923. Aroma-producing microorganisms. J. Bacteriol. 8:393-419.

19. Saito, H., and K. Miura. 1963. Preparation of transforming deoxyribonucleic acid by phenol treatment. Biochim. Biophys. Acta 72:619-629.

20. Schleifer, K. H. 1970. Die Mureintypen in der Gattung Microbacterium. Arch. Mikrobiol. 71:271-282.

21. Schleifer, K. H., I. Hayn, H. P. Seidl, and J. Firl. 1983. Threo- $\beta$-hydroxyornithine: a natural constituent of the peptidoglycan of Corynebacterium species Co 112. Arch. Microbiol. 134:243-246.

22. Schleifer, K. H., and O. Kandler. 1972. Peptidoglycan types of bacterial cell walls and their taxonomic implications. Bacteriol. Rev. 36:407-477.

23. Skerman, V. B. D., V. McGowan, and P. H. A. Sneath (ed.). 1980. Approved lists of bacterial names. Int. J. Syst. Bacteriol. 30:225-420.

24. Soppeland, L. 1924. Flavobacterium suaveolens, a new species of aromatic bacillus isolated from dairy water. J. Agric. Res. 28:275-276.

25. Suzuki, K., and K. Komagata. 1983. Taxonomic significance of cellular fatty acid composition in some coryneform bacteria. Int. J. Syst. Bacteriol. 33:188-200.

26. Takeuchi, M., and A. Yokota. 1991. Reclassification of strains of Flavobacterium-Cytophaga group in IFO Culture Collection. Inst. Ferment. Res. Commun. (Osaka) 15:83-96.

27. Topping, L. E. 1937. The predominant microorganisms in soils. 
I. Description and classification of the organisms. Zentralbl. Bakteriol. Parasitenkd. Infektionskr. Hyg. Abt. 2 97:289-304.

28. Uchida, K., and K. Aida. 1977. Acyl type of bacterial cell wall: its simple identification by colorimetric method. J. Gen. Appl. Microbiol. 23:249-260.

29. Wako Pure Chemical Industries, Ltd. 1989. Technical note on the system of PTC-amino acid analysis. Wako Pure Chemical Industries, Ltd., Osaka, Japan. (In Japanese.)
30. Weeks, O. B. 1974. Genus Flavobacterium, p. 357-364. In R. E. Buchanan and N. E. Gibbons (ed.), Bergey's manual of determinative bacteriology, 8th ed. The Williams and Wilkins Co., Baltimore.

31. Yamada, K., and K. Komagata. 1972. Taxonomic studies on coryneform bacteria. IV. Morphological, cultural, biochemical, and physiological characteristics. J. Gen. Appl. Microbiol. 18:399-416. 